\title{
VÄITÖSLUENTO
}

\section{Malli käyttäjäkeskeisen suunnittelun johtamiseen julkisella sektorilla}

\author{
Heli Kautonen \\ Aalto-yliopisto \\ heli.kautonen@gmail.com \\ https://orcid.org/0000-0001-6652-1165
}

TaM Heli Kautonen väitteli 22.2.2019 Aalto-yliopiston perustieteiden korkeakoulussa aiheesta "BAIST-viitemalli julkista arvoa tuottavaan digitaaliseen palvelun käyttäjäkeskeiseen suunnitteluun". Vastaväittäjänä toimi professori Netta Iivari (Oulun yliopisto), ja kustoksena professori Marko Nieminen (Aalto-yliopiston perustieteiden korkeakoulu). Tietotekniikan alaan kuuluva väitöskirja on julkaistu sarjassa Aalto university publication series: doctoral dissertations, ja se on luettavissa myös Aalto-yliopiston Aaltodoc-julkaisuarkistossa osoitteessa http://urn.fi/URN: IS$\mathrm{BN}:$ 978-952-60-8374-2.

Lektiota on kevyesti toimitettu kirjallisessa muodossa julkaisemista varten.

Asiasanat: käyttäjäkeskeinen suunnittelu; julkiset palvelut; digitalisaatio; tietojärjestelmät

Arvoisa kustos, arvoisa vastaväittäjä, arvoisat kuulijat,

Mitä jos voisitte luottaa siihen, että kaikkia teidän arkisia työvälineitänne ovat olleet tekemässä käyttäjäkeskeisen suunnittelun ammattilaiset. Että etenkin tietojärjestelmähankintoihin - esimerkiksi teidän omassa kirjastossanne, arkistossanne tai museossanne palkataan käyttöliittymä- tai palvelumuotoiluArtikkeli on lisensoitu Creative Commons Nimeä-EiKaupallinen-JaaSamoin 4.o Kansainvälinen -lisenssillä 
ammattilaisten osaamista heti projektin alusta alkaen. Ja että tästä osaamisesta ei ensimmäisenä nipistetä, jos budjetti uhkaa huveta.

Mitä jos voisitte olla varmoja, että teidän tarpeitanne kuunnellaan ennen kuin teille annetaan käytettäväksi uusi julkinen verkkopalvelu. Että teitä tai teidän kollegojanne pyydetään osallistumaan työpajoihin tai käyttäjätesteihin, niin että vaikkapa kulttuuriperintöaineistoa tarjoavan järjestelmän kehittäjät pystyvät tekemään siitä paremman.

Mitä jos tietäisitte, että teidän panostustanne arvostetaan. Että teidän antamaanne palautetta ja esittämiänne toiveita oikeasti puntaroidaan ja otetaan mahdollisuuksien mukaan huomioon palvelun tai tietojärjestelmän uutta versiota toteutettaessa.

Kun nykyään saamme käteemme uuden älylaitteen tai alamme käyttää uutta kaupallista verkkopalvelua, voimme olla melko varmoja, että käyttöliittymäsuunnittelijoiden, palvelumuotoilijoiden tai muiden käyttäjäkeskeisen suunnittelun ammattilaisten osaamista on hyödynnetty. Voimme olla melko varmoja, että käyttäjien tarpeita on ainakin jossain määrin kartoitettu, vähintään muutamia käyttäjiä osallistettu yhteiskehittämiseen tai testeihin, ja että kerättyä tieto on otettu tavalla tai toisella huomioon.

Julkisen palvelun osalta mielikuvamme on vielä valitettavasti toisenlainen.

Julkishallinnon digitalisoinnissa on monia haasteita ja yhdeksi niistä on tunnistettu asiakaskeskeisyyden tai, toisella termillä ilmaistuna, käyttäjäkeskeisyyden puute. Aiheen yhteiskunnallinen merkittävyys näkyy siinä, että niin tämänhetkinen hallituksemme kuin muutama edellinenkin ovat pyrkineet ohjamaan julkishallinnon toimijoita parantamaan palvelujensa laatua. Itse toivon, että käyttäjäteema on vahvasti esillä myös tulevien vaalien jälkeen, sillä tekoälyn aikakaudella ihmisen ja teknologian vuorovaikutuksen soisi olevan edelleen merkittävä yhteiskunnallinen huolenaihe.

Jos kaupallinen toimija tarjoaa huonon tuotteen tai palvelun, ihmiset etsivät nopeasti itselleen helppokäyttöisempiä ja laadukkaampia vaihtoehtoja. Julkisen palvelun asiakas, kansalainen joutuu sen sijaan usein sinnittelemään sen ainoan tarjolla olevan vaihtoehdon kanssa tai totuttautumaan itselleen vieraalla tavalla toimiviin verkkopalveluihin. Julkisen palvelun puutteellinen suunnittelu johtaa helposti suurten ihmisjoukkojen turhautumiseen.

Olen tänään tarkastettavassa väitöstutkimuksessa paneutunut ongelmana olevaan ilmiöön tieteellisen tutkimuksen keinoin. Tutkimuksen pohjalla on lähes kahden vuosikymmenen työura julkisen sektorin tietojärjestelmien kehittämisessä. Olen siis itse ollut mukana ylläpitämässä vallalla olevia käytäntöjä, mutta myös muuttamassa niitä parhaan ymmärrykseni mukaan. Taideteollisen korkeakoulun kasvattina, taiteen maisterina ajattelin alkuun, että suunnittelijan luovuudesta ja kyvykkyydestä riippuu, onnistuuko loppu- 
tulos eli onko vaikkapa verkkopalvelu käyttäjilleen hyvä vai huono. Näkökulmani on vuosi vuodelta tästä laajentunut. Nyttemmin, asiaa tutkittuani, ymmärrän hyvän käytettävyyden ja käyttäjäkokemuksen olevan paljon monimutkaisemmin hallittavissa ja varmistettavissa.

Tein tutkimusta Aalto-yliopistossa, suunnittelutieteellisellä otteella, joten en lähtenyt etsimään syitä eli kysymään miksi, vaan etsin ratkaisuja ja kysyin alkuun, miten tai mitä ja lopuksi millainen. Tutkimustyö käynnistyi seuraavista mieltäni askarruttaneista kysymyksistä: Jos julkinen toimija haluaa edistää digitaalisen palvelunsa käyttäjäkeskeisyyttä, mitä aktiviteetteja organisaation tulisi tai kannattaisi tehdä? Miten paljon työhön tulisi tai kannattaisi panostaa? Mitä hyötyä tai arvoa käyttäjäkeskeisestä suunnittelusta oikeastaan on?

Tapani tutkia on korkealta katsova ja laajalle levittäytyvä. Olen tehnyt tutkimusta seitsemän vuoden aikana ja kirjoittanut sinä aikana viisi tähän väitöskirjaan kuuluvaa artikkelia, sekä yhteenvetona koosteen. Olen tarkastellut näinä vuosina itseäni lähimpänä ollutta julkisen digitaalisen palvelun kehittämisprojektia Finna ja käyttänyt sitä esimerkkitapauksena, mutta olen kerännyt sen rinnalle tutkimusaineistoa myös muista julkisen sektorin tietojärjestelmähankkeista. Olen yhdistänyt tutkimusta arjen kehittämistoimintaan ja käsitteellistä pohdintaa elävästä elämästä keräämäni empiirisen aineiston tarkasteluun.

Haluan tutkimuksellani lisätä ymmärrystä tietojärjestelmien käyttäjäkeskeisestä suunnittelusta organisaation strategisina toimintoina. Olen tarkastellut vallitsevia olosuhteita myös kriittisesti, pyrkien tunnistamaan sellaista omaa ja muiden ihmisten toimintaa, joka jarruttaa käyttäjäystävällisten palvelujen syntyä. Tutkimus sijoittuu suunnittelutieteiden alueelle, joten se sisältää uutta luovia, konstruktiivisia osia. Niistä tärkein on käyttäjäkeskeisen suunnittelun kokonaisuutta kuvaava viitemalli nimeltään BAIST.

BAIST-viitemalli linkittää suunnittelutyön hyötyihin (Benefits, B), toimintoihin (Activities, $A$ ) ja panostukseen (Investments, $I$ ) työhön osallistuvat tai osallistettavat moninaiset sidosryhmät (Stakeholders, $S$ ). Aiemmista käyttäjäkeskeisen suunnittelun johtamisen tarkastelutavoista poiketen viitemalliin sisältyy myös suunnittelutyötä määrittelevä ja sen myötä rakentuva ajallisuuden elementti (Time, T). Työstämisten jälkeen malli kiteytyi timantin muotoiseksi.

Mallin tarkemman esittelyn sijaan pohjustan myöhempää keskustelua kolmella keskeisellä käsitteellä, joihin myös väitöskirjani otsikko viittaa.

Ensimmäinen käsite on käyttäjäkeskeinen suunnittelu. Se tarkoittaa sellaista lähestymistapaa suunnitella tuotteita tai palveluita, jossa otetaan huomioon suunnittelun kohdetta käyttävä ihminen. Olen ollut kiinnostunut tästä aihealueesta jo 90-luvulta lähtien, joten olen nähnyt myös siihen liittyvien 
käsitteiden syntyvän, vakiintuvan ja muuttuvan epätrendikkäiksi. Itse näen tärkeänä näiden käsitteiden takana olevan ilmiön ytimen ja sen, mitä kukin käsite tarjoaa maailmassa olevien ongelmien ratkaisemiseksi. Siksi olen taustoittanut tutkimustani kirjallisuudella käytettävyydestä, inhimillisistä tekijöistä, käyttäjäkokemuksesta, osallistavasta suunnittelusta, yhteismuotoilusta, tuotemuotoilusta, palvelumuotoilusta, muotoiluajattelusta sekä ylipäätään suunnittelusta/muotoilusta.

Toinen keskeinen käsite on julkinen digitaalinen palvelu. Se tarkoittaa julkisin varoin tuotettua tai julkiseen käyttöön tarkoitettua palvelua, jolla on vaikutus kansalaisiin. Digitaalinen palvelu perustuu vuorovaikutteiseen teknologiaan, edellyttää tietojärjestelmiä ja on usein yhteydessä muihin tietojärjestelmiin tietoverkkojen välityksellä. Käsitteen sana palvelu viittaa siihen, että kyse on kuitenkin ihmisten välisestä vuorovaikutuksesta ja digitaalinen teknologia toimii vain alustana tälle vuorovaikutukselle.

Julkista digitaalista palvelua tuottavat julkiset organisaatiot. Koska vain osa näiden palvelujen edellyttämistä tietojärjestelmistä tuotetaan julkisten organisaatioiden omin voimin, julkisten digitaalisten palvelujen suunnitteluun ja toteutukseen osallistuu usein myös kaupallisia toimijoita.

Kolmas ja itselleni suurimpiin oivalluksiin johtanut käsite on julkinen arvo. Julkinen arvo tarkoittaa julkisesta toiminnasta ja palvelutuotannosta syntyvää arvoa. Julkinen arvo ei ole sama asia kuin yrityksen liikevoitto, muttei myöskään sama kuin näinä päivinä julkisen sektorin palveluille niin hanakasti esitetty tuottavuusvaade. Julkinen arvo muodostuu kokemuksista ja yhteisöissä. Se on moniulotteista eli siihen sisältyy yksilöllisiä tarpeita, mutta myös yhteisöllisiä normeja ja toiveita. Julkinen arvo on emergenttiä eli sitä ei voi määritellä etukäteen, vaan se syntyy vasta toimijoiden ja palvelujärjestelmän välisessä vuorovaikutussuhteessa, palvelutoiminnan tuloksena.

Julkinen arvo on näiden ominaisuuksiensa vuoksi kieltämättä vaikeammin määriteltävissä ja mitattavissa kuin yritystoiminnan arvo. Yksi tutkimukseni tuomista oivalluksista on se, että käyttäjäkeskeinen suunnittelu voi tarjota keinoja julkisen arvon haltuun ottamiseen ja digitaalisten palvelujen julkisen arvon tuottamiseen.

Mutta mikä yhteys on tämän organisaation toiminnallaan tuottaman julkisen arvon ja käyttäjäkeskeisen suunnittelun välillä? Vastaan siteeraamalla kahta haastattelemaani henkilöä tutkimuksen viimeisestä vaiheesta.

Ensimmäinen sitaatti on yliopiston opettajalta, jonka kurssilaiset olivat osallistuneet Finnan käyttäjäfoorumille ja saaneet tehtäväkseen ideoida parempaa arkistoaineistojen esittämistapaa. 
Ne opiskelijat jotka oli viime syksynä mukana, niin ne tajusi sen aikana enemmän monia semmosia asioita (näistä aineistoista) kun ne sai ite tehdä ja miettiä. Niille varmaan monen muun tällasen järjestelmän kanssa, tai muutenkin tiedonhaun kannalta, ... siit on niille hyötyä. ... ne saa siitä sellaisia eväitä, joilla ne tekee myöhemmin itse.

Toinen haastateltava on erään pääkaupunkiseudun lähiössä sijaitsevan yleisen kirjaston virkailija, joka on ollut mukana saavutettavan kirjaston kehittämisessä.

Käyttäjäkeskeinen suunnittelu lisää luottamusta palvelua toimittavaan organisaatioon ja yhteiskuntaan, ja lisäksi... Kun mä opastan asiakkaita vaikka digipalveluiden käytössä, yhden toimivan digitaalisen palvelun käyttö luo valmiuksia käyttää muitakin digitaalisia palveluita, joka taas edesauttaa kansalaistaitoja ja kansalaisena selviytymistä, koska kaikki on jossain määrin tai tulee olemaan digitaalista. Mä ajattelen, että onnistunut käyttäjälähtöinen suunnittelu jossakin palvelussa, jossa kohderyhmänä on jollain tapaa ehkä haavoittuvassa asemassa olevia ihmisiä tai ihmisiä, joilla on erinäisiä vaikeuksia, ... Se on enemmän kuin vain luottamusta. Se lisää luottamusta paitsi organisaatioon, yhteiskuntaan, se lisää luottamusta myös itseen.

Suunnittelu tähtää aina muutokseen. Suunnittelutieteellisen tutkimuksen on tarkoitus tuoda jokin uusi näkökulma tieteelliseen keskusteluun. Oma tutkimukseni täydentää olemassa olevia käsityksiä käyttäjäkeskeisestä suunnittelusta ehdottamalla, että aika on yksi suunnittelutyössä huomioon otettavista elementeistä. Erityisesti julkisia palveluja tuotettaessa ajalla on strategista merkitystä: Hyvin suunniteltu ja käyttäjäystävällinen palvelu tuottaa toki välitöntä hyötyä käyttäjilleen, mutta osa sen hyödyistä voi tulla näkyväksi julkisena arvona vasta hyvinkin pitkän ajan jälkeen.

Siispä päätän johdantoni kysymykseen: Mitä jos olisi itsestään selvää, että julkisrahoitteisen digitaalisen palvelun hyödyistä ja julkisesta arvosta keskustellaan avoimesti. Että vaikkapa tieteen infrastruktuuripalvelun suunnitteluun kuuluisivaihe, jossa käyttäjiltäja muiltakeskeisiltäsidosryhmiltäkysytään, mitä ollaan tavoittelemassa - ei pelkästään lyhyellä tähtäimellä vaan myös vuosien päästä. 